\title{
Trade Credit and Taxes
}

\section{Citation}

Desai, Mihir, C. Fritz Foley, and James R. Hines Jr. "Trade Credit and Taxes." Review of Economics and Statistics 98, no. 1 (March 2016): 132-139.

\section{Published Version}

https://www.mitpressjournals.org/doi/abs/10.1162/REST_a_00534?journalCode=rest

\section{Permanent link}

http://nrs.harvard.edu/urn-3:HUL.InstRepos:41275360

\section{Terms of Use}

This article was downloaded from Harvard University's DASH repository, and is made available under the terms and conditions applicable to Other Posted Material, as set forth at http:// nrs.harvard.edu/urn-3:HUL.InstRepos:dash.current.terms-of-use\#LAA

\section{Share Your Story}

The Harvard community has made this article openly available.

Please share how this access benefits you. Submit a story.

\section{Accessibility}




\title{
TRADE CREDIT AND TAXES
}

\author{
Mihir A. Desai, C. Fritz Foley, and James R. Hines Jr.*
}

Abstract-This paper analyzes the extent to which tax differences affect the use of trade credit. U.S.-owned affiliates in low-tax countries use trade credit to lend, whereas those in high-tax countries use trade credit to borrow: $10 \%$ lower local tax rates are associated with net trade credit positions that are $1.4 \%$ higher as a fraction of sales. The use of trade credit to get capital out of low-tax, low-return environments is also illustrated by the temporary repatriation tax holiday in 2005 , which was used most intensively by affiliates with positive net trade credit positions.

\section{Introduction}

$\mathrm{B}^{\mathrm{s}}$ USINESS transactions are commonly conducted on the basis of credit, as a result of which a seller does not receive cash but instead the promise of a future payment, which it records as an account receivable, and a buyer incurs an obligation, which it records as an account payable. At a given time, firms will have both accounts receivable and accounts payable, which collectively are known as trade credit. The U.S. corporate sector reported aggregate accounts receivable of $\$ 13.0$ trillion and accounts payable of $\$ 5.3$ trillion at year-end 2011, which are sizable figures even relative to its annual business receipts of $\$ 28.3$ trillion and net income of $\$ 1.3$ trillion. $^{1}$

This paper examines the extent to which taxation influences trade credit practices by affecting returns to investment. High rates of taxation generally increase the cost of capital, reducing investment levels and driving up pretax returns. As a result, tax rate differences create incentives to transfer capital from low-tax, low-capital-cost, low-return users to high-tax, high-capital-cost, high-return users by delaying or accelerating the payment of trade accounts. The evidence suggests that tax-induced borrowing and lending through trade accounts is of similar magnitude to tax effects on borrowing and lending through conventional bond issuance and bank loans.

The effects of taxation on the use of trade credit are most readily observed internationally, where tax rate differences are sizable and apparent. Foreign affiliates of U.S. multinational firms make extensive use of trade credit: at year-end 2004 , these affiliates held accounts receivable of $\$ 1.49$ tril-

Received for publication April 6, 2013. Revision accepted for publication January 5, 2015. Editor: Gordon Hanson.

* Desai: Harvard University and NBER; Foley: Harvard University and NBER; Hines: University of Michigan and NBER.

The statistical analysis of firm-level data on U.S. multinational companies was conducted at the Bureau of Economic Analysis, U.S. Department of Commerce under arrangements that maintain legal confidentiality requirements. The views expressed are those of the authors and do not reflect official positions of the U.S. Department of Commerce. We thank seminar participants at Columbia Law School, Harvard Law School, Oxford University, the University of Illinois at Urbana-Champaign, the University of Michigan, the UNC Tax Symposium, and ITPF for helpful comments. Gordon Hanson and three anonymous referees offered many constructive suggestions that are incorporated in this draft. C.F. and M.D. thank the Division of Research of the Harvard Business School for financial support.

${ }^{1}$ These data are drawn from 2011 corporate tax returns, available at http://www.irs.gov/pub/irs-soi/11 coccr.pdf. lion and had accounts payable of $\$ 1.39$ trillion; each of these exceeded $30 \%$ of total annual affiliate sales. The analysis of detailed affiliate-level data suggests that tax effects are large and statistically significant in explaining trade credit choices.

Figure 1 offers descriptive evidence, drawn from published BEA data, of the extent to which tax incentives may influence the use of trade credit by multinational affiliates. The figure presents information on the foreign affiliates of U.S. multinational firms sorted by tax rates in their host foreign countries. The figure shows that accounts receivable and accounts payable, as well as differences between the two, are greater in low-tax jurisdictions than in high-tax jurisdictions, a pattern that is consistent with incentives to use trade credit to allocate capital to places where it generates high pretax returns.

Regressions using parent company fixed effects confirm that affiliates in high-tax countries have smaller net working capital positions than do other affiliates; higher tax rates are associated with greater borrowing through trade accounts that is similar in magnitude to the additional nontrade account borrowing commonly associated with higher tax rates. The association of tax rate differences and net working capital positions is strongest for wholly owned affiliates and those with fewer idiosyncratic capital needs as indicated by low capital expenditures.

Responses to recent changes in U.S. international tax policy offer additional evidence of the use of trade credit to reallocate capital to more productive uses. The 2004 U.S. Homeland Investment Act greatly lowered the cost of reallocating capital to the United States by permitting many firms to pay U.S. tax on only $15 \%$ of the dividends they received from foreign affiliates during 2005 . Foreign affiliates with positive net working capital positions prior to 2005 responded to the tax change by paying greater dividends to their parent companies and reducing their holdings of working capital more sharply than did other affiliates. These reactions are consistent with pre-2005 use of trade credit to reallocate capital to locations where it earns higher returns and the emergence in 2005 of a more permanent and cost-effective method of doing so.

Existing work emphasizes explanations for the use of trade credit that are unrelated to taxes. Several papers, including Burkart and Ellingsen (2004), Giannetti, Burkart, and Ellingsen (2011), Cunat (2007), and Fabbri and Menichini (2010), highlight the ability of suppliers to lend in a way that limits managerial opportunism more effectively than can financial lenders. Other studies, such as Lee and Stowe (1993), Long, Malitz, and Ravid (1993), Ng, Smith, and Smith (1999), and Antràs and Foley (2015), explain how trade credit arrangements solve information problems concerning product quality and buyer credit-worthiness. 


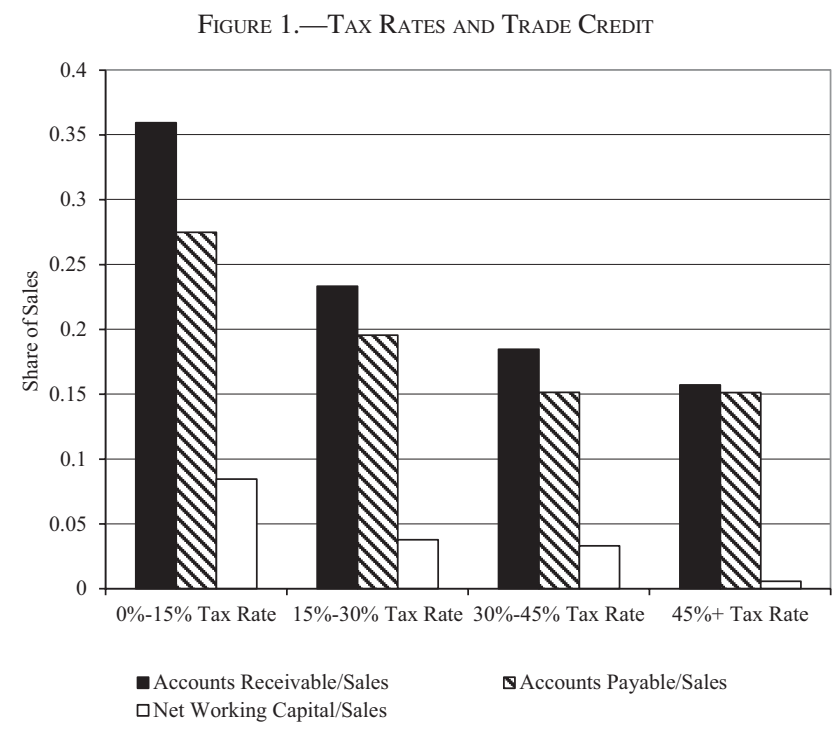

This figure displays mean measures of trade credit use by foreign affiliates of U.S. firms in countries with differing corporate tax rates. Accounts receivable/sales is the ratio of total current accounts receivable to total annual sales; accounts payable/sales is the ratio of total current accounts payable to tota sales; and net working capital/sales is the ratio of the difference between total current accounts receivable and current accounts payable to total sales. Ratios are computed using the publicly available BEA country-level data for the 1982, 1989, 1994, 1999, and 2004 benchmark years that cover nonbank majority-owned affiliates of nonbank parents. Average tax rates are calculated as ratios of total income tax payments to total pretax income. The left-most set of bars depicts ratios for U.S. multinaitonal affiliates located in countries with average corporate tax rates below $15 \%$. The second set of bars depicts ratios for U.S. multination affilites located in countries with tax rates greater than or equal to $15 \%$ and less for U.S. multinational affiliates located in countries with tax rates greater than or equal to $15 \%$ and less tha retes rates greater than or equal $30 \%$ and less than $45 \%$, and he right-most set of bars depicts ratios for U.S. multinational affiliates located in countries with tax rates greater than or equal to $45 \%$.

Relatedly, Petersen and Rajan (1994) present evidence that monitoring provided by suppliers might aid firms in accessing financial lenders, who can free-ride on the monitoring provided by suppliers. Trade credit decisions also appear to reflect the bargaining power of buyers and suppliers, as indicated by Klapper, Laeven, and Rajan (2012). Fisman and Love (2003), and Love, Preve, and Sarria-Allende (2007), identify some of the consequences of access to trade credit. Meltzer (1960) and Ramey (1992) explain trade credit as a means of reallocating capital across firms, though the motives for this reallocation are unrelated to taxes. Of course, these different explanations for the use of trade credit, and explanations related to tax incentives, are not mutually exclusive.

A few studies consider tax motivations for the use of trade credit. Brick and Fung (1984) consider the implications of a cash accounting regime, in which transactions are taxed when payments are made. In such a setting, heavily taxed firms have incentives to extend credit to lightly taxed firms, thereby deferring receipt of cash and the recognition of tax liabilities. Most corporations, however, including all publicly traded corporations, are required to use accrual accounting for tax purposes. Under accrual accounting, a firm must pay tax on income as it accrues, so is taxed on the proceeds of a completed sale even when cash is not yet received. Mian and Smith (1992) note that heavily taxed sellers might be able to defer tax liabilities by using installment sales that are permitted under IRS rules and allow taxpayers using accrual accounting to defer recognizing sales revenue until cash is actually received. Brennan, Maksimovic, and Zechner (1988) also consider the tax treatment of installment sales, but conclude that they do not reduce the present value of tax liabilities. Under IRS rules, if sellers defer income recognition, then buyers are unable to claim tax deductions for expenses until payment is actually made. Furthermore, the special tax treatment of installment sales is available only in certain circumstances involving sales of capital assets; it is not available for the vast majority of corporate sales, including sales of inventory property and services. $^{2}$

\section{Understanding the Impact of Taxes on Trade Credit}

Two corporations that buy and sell items from each other can pay at the time of purchase or at another time, in the meantime creating, respectively, accounts payable and accounts receivable. Corporations are required to use the accrual method in calculating their tax liabilities, so income is taxable when it is earned, not necessarily when it is received. Consequently, a corporation must pay income taxes on sales to another party even if it has not yet received payment, as long as the sale has taken place and the buying party can reasonably be expected to make that payment eventually.

Consider a setting in which firm $i$, which could be a U.S. multinational parent company, purchases a good worth $\$ 1$ from firm $j$, which could be a foreign affiliate of that parent, at the start of a year and faces the question of whether to pay immediately. If firm $i$ delays payment, it accrues an account payable that it will settle at the start of the following year with interest $r$, so next year it pays $(1+r)$. As a result of not paying this year, firm $i$ has the use of an additional dollar of capital for the year, thus increasing its financial capital $K_{i}$, and firm $j$ forgoes the use of the same dollar of capital, thus decreasing $K_{j}$. Denote firm $i$ 's production function by $Q_{i}\left(K_{i}\right)$; the delayed payment then nets firm $i$ after taxes:

$$
\left[Q_{i}^{\prime}\left(K_{i}\right)-r\right]\left(1-\tau_{i}\right)
$$

in which $\tau_{i}$ is the tax rate facing firm $i$. Expression (1) reflects both that the additional income is taxable and that firm $i$ is entitled to deduct from taxable income the interest component of its settlement of the account payable to firm $j$. Similarly, firm $j$ loses the benefit of using $\$ 1$ of financial capital for a year but receives interest, so after taxes, it nets

$$
\left[r-Q_{j}^{\prime}\left(K_{j}\right)\right]\left(1-\tau_{j}\right) .
$$

Expressions (1) and (2) can be viewed as participation constraints in which both parties have incentives to use trade credit if $Q_{i}^{\prime}\left(K_{i}\right) \geq r \geq Q_{j}^{\prime}\left(K_{j}\right)$. By delaying payment,

\footnotetext{
${ }^{2}$ Graetz and Schenk (2009) review the interpretation and application of U.S. tax law to corporate accounts receivable and accounts payable.
} 
firm $i$ effectively borrows from firm $j$ and benefits from this trade due to a difference in pretax marginal products of capital. If the pattern of pretax marginal products of capital were reversed, so that $Q_{i}^{\prime}\left(K_{i}\right)<Q_{j}^{\prime}\left(K_{j}\right)$ and $r$ lies between them, then firm $j$ is a more productive user of capital than firm $i$, and both can benefit by having firm $i$ prepay for its purchase.

The advantage of using trade credit is manifest by summing expressions (1) and (2) to obtain the joint benefit generated by the contemplated delayed payment:

$$
Q_{i}^{\prime}\left(K_{i}\right)\left(1-\tau_{i}\right)-Q_{j}^{\prime}\left(K_{j}\right)\left(1-\tau_{j}\right)+r\left(\tau_{i}-\tau_{j}\right)
$$

The joint benefit consists of the difference between the after-tax marginal products of capital, as given by the first two terms of expression (3), and the tax-advantaged location of interest payments and receipts, as given by the third term. If after-tax marginal products of capital are equal, an implication of equity-financed investment with a common cost of capital, ${ }^{3}$ then the first two terms offset each other and there is a gain to the transaction if $\tau_{i}>\tau_{j}{ }^{4}$ All other considerations equal, larger tax rate differences induce greater reallocations of capital. Trade credit, just like debt, reduces the distortion to investment levels created by the corporate tax by encouraging firms to reallocate investment to higher tax locations.

Instead of employing trade credit arrangements, customers might exchange cash for goods at the time of sale, financing their expenditures, if need be, with loans from local banks. Bank loans serve many of the same functions as trade credit, though terms and conditions of bank loans are likely to differ from trade terms offered by suppliers because banks and suppliers have different relationships with buyers and access to different information, and they can draw on

\footnotetext{
${ }^{3}$ The assumption of equity finance is a common starting place in the analysis of the effect of corporate taxation, since if corporate investment is instead debt financed, then there is effectively no corporate tax: a firm that is $100 \%$ debt financed, with an average return on investment equal to the interest rate, has interest deductions that exactly offset its taxable income, leaving zero corporate tax to be paid (Auerbach, 2002). The evidence that high tax rates discourage investment, together with the hundreds of billions of dollars collected by the U.S. corporate tax each year, suggests that in practice, corporations are not entirely debt financed. Hassett and Hubbard (2002), Chirinko, Fazzari, and Meyer (1999), Desai and Goolsbee (2004), Djankov et al. (2010), Da Rin, Giacomo, and Sembenelli (2011), and Bond and Xing (2010) offer evidence of the impact of corporate tax rates on investment. Graham (2000) measures the extent to which firms borrow too little from a tax standpoint; he estimates that the average firm in his sample could double its debt-related tax benefits by taking on additional debt.

${ }^{4}$ The third term of expression (4) corresponds to the net value of interest tax deductions in the high-tax jurisdiction and taxes on interest income in the low-tax jurisdiction, reflecting that trade credit reallocates capital in a manner that is treated for tax purposes like borrowing. Since higher tax rates are consistently associated with greater propensity to use debt finance (Graham, 1996; Desai, Foley, \& Hines, 2004b; Huizinga, Laeven, \& Nicodème, 2008), it follows that firms facing high corporate tax rates should be expected to borrow using trade credit, whereas those facing low corporate tax rates should be expected to use trade credit to loan to other firms.
}

differing expertise. In practice, information and enforcement costs limit the availability of inexpensive bank loans and trade credit borrowing, and tax rules can restrict the extent of deductible interest payments. As a result, trade credit is often an attractive method of borrowing.

\section{Evidence from U.S. Multinational Firms}

Data used to analyze the financing and operations of U.S. firms are drawn from the BEA annual survey of U.S. direct investment abroad. Although many data items, such as sales, are collected for a broad sample on an annual basis, detailed data on trade credit are available for larger affiliates only in 1982, 1989, 1994, 1999, and 2004, years in which BEA conducted benchmark surveys. In these years, surveys captured information on current trade accounts and trade notes receivable, as well as current trade accounts and trade notes payable. ${ }^{5}$ In the analysis that follows, these measures are scaled by sales. ${ }^{6}$ Net trade credit positions are measured in the data as differences between accounts receivable and accounts payable scaled by sales.

Data on foreign income taxes paid and net income can be used to calculate foreign corporate income tax rates; each affiliate's average tax rate is the ratio of foreign income tax payments to the sum of net income and foreign income tax payments. Countries are then assigned tax rates equal to median tax rates among local U.S. affiliates. This tax burden measure has the disadvantage of being partly a function of the average behavior of U.S. investors but offers the advantage of reflecting not only statutory corporate tax rates but also the values of tax depreciation and other business deductions, tax credits, tax holidays, and other features of national tax systems that can significantly influence tax obligations; as a result, it is widely employed by studies of U.S. multinationals (Desai, Foley, and Hines 2001, 2004a, 2004b, 2006; Blouin et al., 2014) that use the BEA data. ${ }^{7}$

The BEA data include information on parent company ownership of affiliates; this information is used to identify the directly owned affiliates whose dividend payments were affected by the 2005 repatriation tax holiday. Precise measures of accounts receivable and accounts payable are not available in the BEA data on an annual basis, but a broader

\footnotetext{
5 In 1982, 1989, and 1994, all affiliates with an absolute value of sales, assets, or net income in excess of \$3 million, \$15 million, and \$50 million, respectively, were required to report accounts receivable and accounts payable. In 1999 and 2004, all majority-owned affiliates with an absolute value of sales, assets, or net income in excess of $\$ 100$ million and $\$ 150$ million, respectively, were required to report accounts receivable and accounts payable.

6 To reduce the potential impact of outliers, accounts receivable/sales, accounts payable/sales, and net working capital/sales are winsorized at the $2.5 \%$ level in each tail of the distribution.

7 The regressions presented in tables 2 and 3 were rerun using three additional tax rate measures: statutory corporate tax rates, average tax rates faced by U.S. affiliates as reported in the BEA data, and (affiliatespecific) average tax rates faced by U.S. firms other than the affiliate whose behavior the regression model predicts. Estimated tax effects in the regressions using these alternative measures, available from the authors, look similar to those reported in tables 2 and 3.
} 
Table 1.-Descriptive Statistics

\begin{tabular}{|c|c|c|}
\hline & Mean & Standard Deviation \\
\hline \multicolumn{3}{|l|}{ Statistics for table 2} \\
\hline Net Working Capital/Sales & 0.0433 & 0.5044 \\
\hline Median Country Tax Rate & 0.3357 & 0.1333 \\
\hline Haven Dummy & 0.1334 & 0.3401 \\
\hline Log of Assets & 10.6473 & 1.8786 \\
\hline Non Trade Account Leverage & 0.2823 & 0.2958 \\
\hline Log of GDP per Capita & 9.2287 & 1.0386 \\
\hline Whole Ownership Dummy & 0.7783 & 0.4154 \\
\hline \multicolumn{3}{|l|}{ Statistics for table 3} \\
\hline Dividends/Sales & 0.0316 & 0.0820 \\
\hline $\begin{array}{l}\text { Directly Owned with Positive Net } \\
\text { Working Capital }\end{array}$ & 0.2513 & 0.4338 \\
\hline Net Income/Sales & 0.0648 & 0.4292 \\
\hline Net Working Capital Ratio & 0.0231 & 0.5264 \\
\hline Log of Assets & 12.6659 & 1.3412 \\
\hline Log of GDP per Capita & 9.8820 & 1.0337 \\
\hline \multicolumn{3}{|c|}{$\begin{array}{l}\text { This table presents descriptive statistics for the main variables used in the analysis presented in the } \\
\text { subsequent tables. Net Working Capital/Sales is the ratio of the difference between current accounts } \\
\text { receivable and current accounts payable to sales. Median Country Tax Rate is the median value of the } \\
\text { ratio of affiliate income tax payments to pretax income in the affiliate's host country. Haven Dummy } \\
\text { equals } 1 \text { for foreign affiliates located in countries identified as tax havens by Hines and Rice (1994). Log } \\
\text { of Assets is the log of total affiliate assets, and Non Trade Account Leverage is the ratio of the difference } \\
\text { between current liabilities and long-term debt and current trade accounts payable to sales. Log of GDP } \\
\text { Per Capita is the log of per capita GDP of the country in which an affiliate is located. Whole Ownership } \\
\text { Dummy is a dummy equal to } 1 \text { for affiliates that are wholly owned by their U.S. parent companies. Divi- }- \text { pare } \\
\text { dends/sales is the ratio of affiliate dividend payments to total affiliate sales. Directly owned with positive } \\
\text { net working capital is a dummy equal to } 1 \text { for affiliates that are directly owned by their U.S. parent com- } \\
\text { panies and have current accounts receivable that exceed current accounts payable in 2004. Net income/ } \\
\text { sales is the ratio of net income to sales. Net working capital ratio is a ratio that is available on an annual } \\
\text { basis; the numerator is equal to current assets minus current liabilities and long-term debt and the } \\
\text { denominator is equal to the sum of current assets, current liabilities, and long-term debt. }\end{array}$} \\
\hline
\end{tabular}

measure is available annually for the years 1999 to 2007: the ratio of current assets minus current liabilities and longterm debt to current assets plus current liabilities and longterm debt. This measure of working capital is not scaled by sales. The broader measures of assets and liabilities on which the ratio is based do not relate closely to sales and scaling the difference in the numerator by sales yields many outliers. By scaling the difference in the numerator by the sum of its components, the measure is restricted to lie between -1 and 1 . Table 1 presents means and standard deviations of variables used in the regressions that follow.

Table 2 presents regressions that explore the impact of local tax rates on trade credit use by U.S. multinational affiliates in foreign countries between 1982 and 2004. The dependent variable in the regressions presented in table 2 is the ratio of net working capital to affiliate sales. All of the regressions presented in table 2 include parent company fixed effects and year fixed effects. Specifications also control for the log of affiliate assets, the log of country GDP per capita, and nontrade account leverage, which is measured as current liabilities and long-term debt less current trade accounts payable, scaled by sales. The -0.1430 coefficient in column 1 suggests that $10 \%$ lower tax rates are associated with net working capital positions that are $1.4 \%$ greater as a fraction of sales.

The regression presented in column 2 analyzes differences between affiliates located in foreign jurisdictions identified as tax havens by Hines and Rice (1994) and affiliates located elsewhere. U.S. multinational firms commonly use affiliates located in tax havens to facilitate indirect own- ership of other foreign affiliates and to serve as intermediaries in trade between related parties. ${ }^{8}$ The 0.0660 coefficient in column 2 of table 2 indicates that tax haven affiliates have significantly larger net working capital positions than do affiliates located elsewhere, the difference corresponding to $6.6 \%$ of sales.

The evidence in table 2 indicates that there is greater trade account borrowing in high-tax locations. Multinational firms commonly also do more nontrade account borrowing in high-tax locations than in low-tax locations, reflecting the benefits of interest expense deductions in high-tax environments. Desai, Foley, and Hines (2004b) find that in the BEA data, $10 \%$ higher foreign tax rates are associated with nontrade account borrowing by foreign affiliates of U.S. multinational firms that is $1.6 \%$ higher as a fraction of assets; ${ }^{9}$ since the mean ratio of nontrade account borrowing to assets in that sample is 0.35 , this is a difference equal to $4.7 \%$ of average borrowing. Since the -0.1430 coefficient in column 1 of table 2 implies that $10 \%$ higher tax rates are associated with $1.4 \%$ greater net borrowing through trade accounts as a fraction of sales, and table 1 indicates that mean nontrade account borrowing as a fraction of sales is 0.28 , it follows that the tax effect on net working capital equals $5.1 \%$ of nontrade account borrowing. This is roughly equal in magnitude to the effect of tax rate differences on more conventional borrowing other than through trade accounts.

The use of trade credit to reallocate capital in response to tax incentives is likely to be most easily facilitated when these entities are under common control, so interacting an indicator of whole ownership with tax variables offers the prospect of identifying the extent to which higher levels of control precipitate observed tax effects. Furthermore, affiliates that face what appear to be highly attractive investment opportunities are unlikely to prefer to extend large amounts of trade credit, regardless of local tax rates, given the potential to earn high returns in local investments. While it is not possible to identify directly the quality of an affiliate's perceived investment opportunities, the affiliate's investment behavior offers an indirect, albeit endogenous, indicator.

Column 3 presents estimated coefficients from a regression that includes a dummy variable for wholly owned affiliates and an interaction of this dummy variable and the local tax rate; the regression is otherwise identical to that reported in column 1 . The -0.1012 coefficient suggests that wholly owned affiliates in low-tax countries have much larger working capital positions than do wholly owned affili-

\footnotetext{
${ }^{8}$ Tax haven affiliates account for $13.4 \%$ of total affiliate sales in the sample; the ratio of aggregate tax haven affiliate account receivables to aggregate sales is $29.3 \%$, and the ratio of aggregate tax haven affiliate account payables to aggregate sales is $23.5 \%$, the difference reflecting the use of trade accounts to do net lending from these locations. By contrast, the ratio of aggregate account receivables to aggregate sales is $32.3 \%$ for affiliates other than those in tax havens, and their ratio of aggregate account payables to aggregate sales is $32.1 \%$.

${ }^{9}$ The magnitude of the estimated tax effect is typical of those reported elsewhere in the literature; see, for example, Huizinga et al. (2008).
} 
Table 2.-TaXes and Net Working Capital Positions

\begin{tabular}{|c|c|c|c|c|c|c|}
\hline \multirow[t]{2}{*}{ Dependent Variable } & \multicolumn{6}{|c|}{ Net Working Capital/Sales } \\
\hline & (1) & (2) & (3) & (4) & (5) & (6) \\
\hline Constant & $\begin{array}{l}-0.1409 \\
(0.0610)^{* *}\end{array}$ & $\begin{array}{l}-0.1248 \\
(0.0557)^{* *}\end{array}$ & $\begin{array}{l}-0.1848 \\
(0.0652)^{* * *}\end{array}$ & $\begin{array}{l}-0.1382 \\
(0.0550)^{* *}\end{array}$ & $\begin{array}{c}-0.0461 \\
(0.0584)\end{array}$ & $\begin{array}{r}-0.0814 \\
(0.0549)\end{array}$ \\
\hline Median Country Tax Rate & $\begin{array}{l}-0.1430 \\
(0.0495)^{* * *}\end{array}$ & & $\begin{array}{l}-0.0538 \\
(0.0426)\end{array}$ & & $\begin{array}{l}-0.1940 \\
(0.0603)^{* * *}\end{array}$ & \\
\hline Haven Dummy & & $\begin{array}{l}0.0660 \\
(0.0229)^{* * *}\end{array}$ & & $\begin{array}{c}-0.0140 \\
(0.0202)\end{array}$ & & $\begin{array}{l}0.0779 \\
(0.0282)^{* * * *}\end{array}$ \\
\hline Whole Ownership Dummy & & & $\begin{array}{l}0.0650 \\
(0.0246)^{* * *}\end{array}$ & $\begin{array}{l}0.0218 \\
(0.0073)^{* * * *}\end{array}$ & & \\
\hline High Capex Dummy & & & & & $\begin{array}{l}-0.1277 \\
(0.0219) * * *\end{array}$ & $\begin{array}{l}-0.0558 \\
(0.0061) * * *\end{array}$ \\
\hline Median Country Tax Rate $\times$ Whole Ownership Dummy & & & $\begin{array}{l}-0.1012 \\
(0.0588)^{*}\end{array}$ & & & \\
\hline Median Country Tax Rate $\times$ High Capex Dummy & & & & & $\begin{array}{l}0.1762 \\
(0.0541)^{* * * *}\end{array}$ & \\
\hline Haven Dummy $\times$ Whole Ownership Dummy & & & & $\begin{array}{l}0.0866 \\
(0.0319)^{* * * *}\end{array}$ & & \\
\hline Haven Dummy $\times$ High Capex Dummy & & & & & & $\begin{array}{l}-0.0709 \\
(0.0261)^{* * *}\end{array}$ \\
\hline Log of Assets & $\begin{array}{c}0.0027 \\
(0.0036)\end{array}$ & $\begin{array}{c}0.0028 \\
(0.0034)\end{array}$ & $\begin{array}{c}0.0030 \\
(0.0036)\end{array}$ & $\begin{array}{c}0.0029 \\
(0.0034)\end{array}$ & $\begin{array}{c}0.0038 \\
(0.0036)\end{array}$ & $\begin{array}{c}0.0038 \\
(0.0032)\end{array}$ \\
\hline Non Trade Account Leverage & $\begin{array}{l}0.2489 \\
(0.0196)^{* * *}\end{array}$ & $\begin{array}{l}0.2508 \\
(0.0193)^{* * *}\end{array}$ & $\begin{array}{l}0.2488 \\
(0.0195)^{* * *}\end{array}$ & $\begin{array}{l}0.2510 \\
(0.0192)^{* * *}\end{array}$ & $\begin{array}{l}0.2514 \\
(0.0194)^{* * * *}\end{array}$ & $\begin{array}{l}0.2533 \\
(0.0192)^{* * *}\end{array}$ \\
\hline Log of GDP per Capita & $\begin{array}{l}0.0161 \\
(0.0043)^{* * *}\end{array}$ & $\begin{array}{l}0.0103 \\
(0.0043)^{* *}\end{array}$ & $\begin{array}{l}0.0142 \\
(0.0042)^{* * * *}\end{array}$ & $\begin{array}{l}0.0094 \\
(0.0042)^{* *}\end{array}$ & $\begin{array}{l}0.0100 \\
(0.0042)^{* *}\end{array}$ & $\begin{array}{c}0.0070 \\
(0.0043)\end{array}$ \\
\hline Parent fixed effects? & Yes & Yes & Yes & Yes & Yes & Yes \\
\hline Year fixed effects? & Yes & Yes & Yes & Yes & Yes & Yes \\
\hline Number of observations & 37,693 & 37,711 & 37,693 & 37,711 & 37,693 & 37,711 \\
\hline$R^{2}$ & 0.1583 & 0.1591 & 0.1588 & 0.1597 & 0.1620 & 0.1624 \\
\hline $\begin{array}{l}\text { This table presents estimated coefficients from regressions explaining the net } \\
\text { of the difference between current accounts receivable and current accounts pay } \\
\text { ate's host country. Haven Dummy equals } 1 \text { for foreign affiliates located in cou } \\
\text { by their U.S. parent companies. High Capital Expenditure Dummy is a dumm } \\
\text { Assets is the log of total affiliate assets, and Non Trade Account Leverage is } \\
\text { Capita is the log of per capita GDP of the country in which an affiliate is locate } \\
\text { that correct for clustering of errors by country are presented in parentheses. Ast }\end{array}$ & $\begin{array}{l}\text { rking capital of for } \\
\text { e to sales. Median } \\
\text { ies identified as tax } \\
\text { qual to } 1 \text { for obser } \\
\text { ratio of the differe } \\
\text { lll regressions are e } \\
\text { ks denote two-taile }\end{array}$ & $\begin{array}{l}\text { affiliates of U.S. } \mathrm{n} \\
\text { ntry Tax Rate is th } \\
\text { ens by Hines and } \mathrm{F} \\
\text { ons in which the r } \\
\text { between current li } \\
\text { ated by ordinary le } \\
\text { gnificance levels: } \mathrm{s}\end{array}$ & $\begin{array}{l}\text { national firms in } 1 \\
\text { edian value of the } \\
\text { (1994). Whole O } \\
\text { of affiliate capital } \\
\text { ities and long-tern } \\
\text { quares and includ }\end{array}$ & $\begin{array}{l}1989,1994,1999 \\
\text { o of affiliate incon } \\
\text { rship Dummy is a } \\
\text { penditures to affili } \\
\text { bt and current trac } \\
\text { ked effects for each } \\
, * * * 99 \% \text {. }\end{array}$ & $\begin{array}{l}\text { ax 2004. The depen } \\
\text { ax payments to pre } \\
\text { nmy equal to } 1 \text { for } \\
\text { assets exceeds the } \\
\text { ccounts payable to } \\
\text { rent firm and for ea }\end{array}$ & $\begin{array}{l}\mathrm{xt} \text { variable is the } \mathrm{r} \\
\mathrm{x} \text { income in the af } \\
\text { ffiliates wholly ow } \\
\text { ample median. Log } \\
\text { ales. Log of GDP } \\
\text { year. Standard err }\end{array}$ \\
\hline
\end{tabular}

ates elsewhere, though this tax effect is statistically significant only at the $10 \%$ level. It is noteworthy that the -0.0538 coefficient on the uninteracted tax rate is quite small and statistically insignificant, implying that tax rate differences have little discernible effect on working capital positions of partially owned affiliates. The regression reported in column 4 uses a tax haven dummy variable in place of the local tax rate, the 0.0866 coefficient indicating that wholly owned affiliates in tax havens have net working capital positions that are $8.6 \%$ larger as a fraction of sales than those elsewhere.

The regressions presented in columns 5 and 6 of table 2 use an indicator of investment opportunities to explore the net working capital implications of the interaction between tax incentives and investment opportunities. The regression reported in column 5 includes a dummy variable that takes the value 1 if an affiliate's capital expenditure-to-asset ratio lies above the sample median; the dummy variable is 0 otherwise. As indicated by the -0.1277 coefficient in column 5, affiliates with above-median capital expenditure to asset ratios have substantially smaller net working positions, reflecting some combination of their demand for, and availability of, investible funds. The -0.1940 coefficient in column 5 indicates that affiliates in low-tax countries have much higher net working capital positions than do affiliates in high-tax countries, but the 0.1762 coefficient reveals that this tax correlation entirely disappears among affiliates with significant capital expenditures. Hence, it appears that tax rate differences are much more strongly associated with net working capital differences among firms without extensive demand for capital expenditures.

A similar pattern appears in the regression reported in column 6 , in which the capital expenditure dummy variable is interacted with a dummy for tax haven location. The 0.0779 coefficient on tax haven location indicates that affiliates in tax havens have significantly larger net working capital accounts than do affiliates located elsewhere, and the -0.0709 coefficient on the interaction reveals that this effect again disappears for affiliates with significant capital expenditures.

Firms without attractive foreign investment opportunities, but with foreign profits that would be subject to high rates of U.S. tax if repatriated, had the strongest incentives to use trade credit arrangements to reallocate capital from foreign affiliates prior to the 2005 repatriation tax holiday. Figure 2 depicts aggregate dividend payout ratios for two samples of foreign affiliates of U.S. firms in 2004 and 2005: the left two bars represent directly owned affiliates that had positive net working capital positions in 2004, and the right two bars represent all others. The shaded bars present 
Figure 2.-Working Capital and Dividend RePatriations

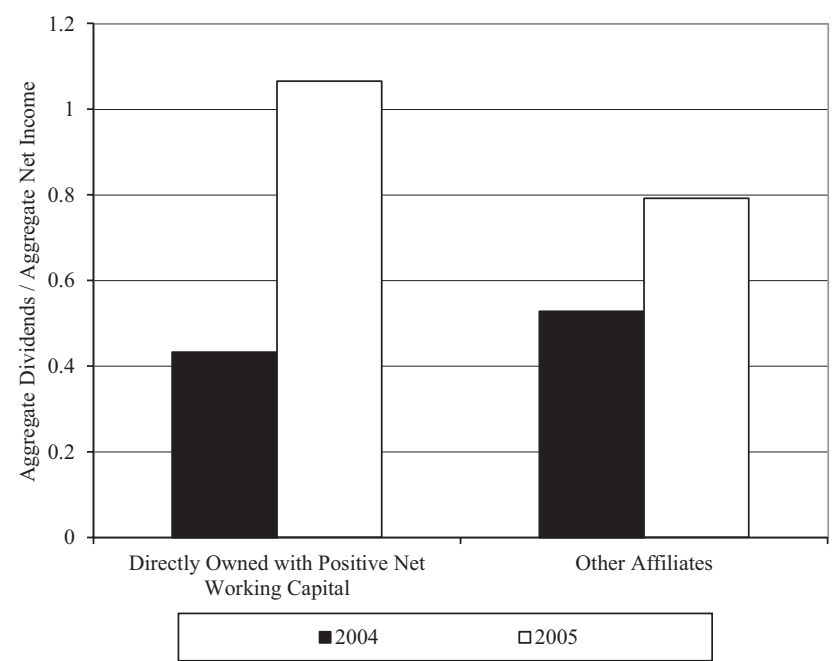

This figure displays aggregate dividend payout ratios for two groups of foreign affiliates of U.S. multinational firms in 2004 and in 2005. Dividend payout ratios are ratios of aggregate dividends paid by U.S. multinational affiliates to aggregate net income of U.S. multinational affiliates. The two left-most bars depict dividend payout ratios of foreign affiliates that are directly owned by U.S parent companies an have positive net working capital positions in 2004. The two right-most bars depict dividend payou ratios of other affiliates. The shaded bars present 2004 dividend payout ratios, and the unshaded bayo preratios of other affilites. sent 2005 dividend payout ratios.

aggregate payout ratios for 2004, and the unshaded bars present payout ratios for 2005. This figure indicates that affiliates with positive net working capital positions prior to the tax change increased their dividend payout ratios much more than did other affiliates, suggesting that they had been using trade credit to reallocate capital previously trapped abroad.

The regressions presented in columns 1 and 2 of table 3 evaluate the extent to which foreign affiliates with positive net working capital positions prior to 2005 took advantage of the repatriation tax holiday to remit dividends to U.S. parent companies. For this purpose, it is necessary to focus on foreign affiliates directly owned by their U.S. parent companies because dividend payments by indirectly owned affiliates would be received by entities other than U.S. parent companies and therefore possibly not included among 2005 repatriations eligible for the tax holiday.

The dependent variable in the regressions reported in columns 1 and 2 of table 3 is the ratio of dividends to affiliate sales. The independent variable Directly Owned with Positive Net Working Capital is a dummy equal to 1 for affiliates that are directly owned and have accounts receivable exceeding accounts payable in 2004 . The 0.0124 coefficient on the interaction of this variable with a dummy for year 2005 in the regression reported in column 1 indicates that directly owned affiliates with positive net working capital positions were more likely to pay dividends during 2005 than in other years; these affiliates were indeed more likely to pay dividends in 2005 than are typical affiliates in typical years, as reflected by the positive sum of the -0.0062 and 0.0124 coefficients. The regression reported in column 1 controls for ratios of net income to sales, whether the affiliate paid a dividend in the previous year, year effects, and parent fixed effects The specification in column 2 includes affiliate fixed effects instead of parent fixed effects, without changing significantly the estimated effect of the 2005 repatriation holiday.

By offering a one-time low-cost means of moving capital out of low-tax jurisdictions, the Homeland Investment Act reduced the incentive for affiliates to use net working capital positions for this purpose. The regressions presented in columns 3 and 4 of table 3 test the hypothesis that affiliates in low-tax jurisdictions reduced their net working capital positions in response to the 2005 holiday. The dependent variable is the ratio of current assets minus current liabilities and long-term debt to current assets plus current liabilities and long-term debt. The tax measure is a dummy equal to 1 for affiliates based in countries with tax rates in the bottom quartile of rates prior to the holiday.

The 0.0764 coefficient on the dummy for affiliates based in low-tax countries in column 3 indicates that these affiliates tend to have higher working capital positions than do other affiliates. The -0.0345 coefficient on the interaction of this dummy and the dummy for the years 2005, 2006, and 2007 indicates that these affiliates reduced their working capital positions relative to other affiliates immediately following the tax holiday. The specification in column 4 includes affiliate fixed effects, with an estimated coefficient on the interaction of low tax rates and years 2005 to 2007 that is similar to that reported in column 3.

\section{Conclusion}

U.S. multinational firms use trade credit to reallocate capital between locations with differing tax rates, reflecting that some of the benefits of direct ownership of foreign operations lie in opportunities for tax-motivated planning (Desai et al. 2004a). Incentives to use trade credit to reallocate capital also appear in settings with trade between unrelated parties. Petersen and Rajan (1997) note that lower-income firms, despite their limited liquidity and high monitoring costs, are more likely than others to lend to unrelated parties via trade credit. One reason may be that lower-income firms, with their greater likelihood of tax losses, in expectation face lower marginal tax rates than others and might therefore find it profitable to use trade credit to reallocate capital to firms with higher tax rates and higher pretax marginal products of capital.

High tax rates encourage borrowing through trade accounts just as high tax rates encourage more conventional forms of borrowing such as bank loans and debt issuance. The evidence in this paper suggests that the additional trade account borrowing associated with higher tax rates is similar in magnitude to the additional conventional borrowing associated with higher tax rates. Concerns over high tax rates encouraging excessive corporate borrowing, with resulting prospects for bankruptcy, are commonly directed at conventional borrowing rather than borrowing through trade accounts, as are remedies such as thin capitalization 
TABLE 3.-TAX Holiday AND REPATRIATIONS

\begin{tabular}{|c|c|c|c|c|}
\hline \multirow[t]{2}{*}{ Dependent Variable } & \multicolumn{2}{|c|}{ Dividends/Sales } & \multicolumn{2}{|c|}{ Net Working Capital Ratio } \\
\hline & (1) & (2) & (3) & (4) \\
\hline Constant & $\begin{array}{l}0.0309 \\
(0.0019) * * *\end{array}$ & $\begin{array}{l}0.0452 \\
(0.0022) * * *\end{array}$ & $\begin{array}{l}0.7500 \\
(0.0599) * * *\end{array}$ & $\begin{array}{c}0.3081 \\
(0.2445)\end{array}$ \\
\hline Directly Owned with Positive Net Working Capital & $\begin{array}{l}-0.0062 \\
(0.0018)^{* * *}\end{array}$ & & & \\
\hline Directly Owned with Positive Net Working Capital $\times 2005$ Dummy & $\begin{array}{l}0.0124 \\
(0.0038)^{* * * *}\end{array}$ & $\begin{array}{l}0.0107 \\
(0.0045)^{* *}\end{array}$ & & \\
\hline Net Income/Sales & $\begin{array}{l}0.0318 \\
(0.0026)^{* * *}\end{array}$ & $\begin{array}{l}0.0199 \\
(0.0038) * * *\end{array}$ & & \\
\hline Lag Dividend/Sales & $\begin{array}{l}0.3269 \\
(0.0166)^{* * * *}\end{array}$ & $\begin{array}{l}-0.0376 \\
(0.0173)^{* *}\end{array}$ & & \\
\hline Low Median Country Tax Rate Dummy & & & $\begin{array}{l}0.0764 \\
(0.0123)^{* * *}\end{array}$ & \\
\hline Low Median Country Tax Rate Dummy × 2005-2007 Dummy & & & $\begin{array}{l}-0.0345 \\
(0.0149) * *\end{array}$ & $\begin{array}{l}-0.0403 \\
(0.0152)^{* * *}\end{array}$ \\
\hline Log of Assets & & & $\begin{array}{l}-0.0452 \\
(0.0036) * * *\end{array}$ & $\begin{array}{l}-0.0297 \\
(0.0078) * * *\end{array}$ \\
\hline Log of GDP per Capita & & & $\begin{array}{l}-0.0116 \\
(0.0046)^{* *}\end{array}$ & $\begin{array}{c}0.0145 \\
(0.0232)\end{array}$ \\
\hline Parent fixed effects? & Yes & No & Yes & No \\
\hline Affiliate fixed effects? & No & Yes & No & Yes \\
\hline Year fixed effects? & Yes & Yes & Yes & Yes \\
\hline Number of observations & 17,764 & 17,764 & 49,009 & 49,009 \\
\hline$R^{2}$ & 0.2319 & 0.4812 & 0.1980 & 0.6876 \\
\hline
\end{tabular}

The dependent variable in the regressions reported in columns 1 and 2 is the ratio of affiliate dividend payments to sales. Directly Owned with Positive Net Working Capital is a dummy equal to 1 for affiliates that are directly owned by their U.S. parent companies and have current accounts receivable that exceed current accounts payable in 2004. The 2005 Dummy is equal to 1 for observations in 2005. Net Income/Sales is the ratio of net income to sales. Lag Dividend/Sales is the previous year's ratio of affiliate dividend payments to annual sales. The dependent variable in columns 3 and 4 is a ratio; the numerator is equal to current assets minus current liabilities and long-term debt, and the denominator is equal to the sum of current assets, current liabilities, and long-term debt. Low Median Country Tax Rate Dummy is a dummy equal to 1 for affiliates based in countries in the lowest quartile when ranked by the median value of the ratio of affiliate income tax payments to pretax income, averaged over the 1999-2004 period. 2005-2007 Dummy is a dummy equal to 1 in the years 2005, 2006, and 2007. Log of Assets is the log of total affiliate assets, and Log of GDP Per Capita is the log of per capita GDP of the country in which an affiliate is located. All regres-

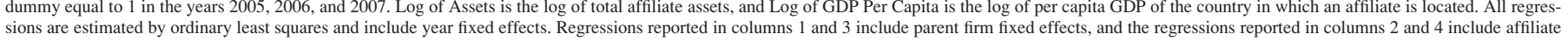
fixed effects. Standard errors that correct for clustering of errors by affiliate are presented in parentheses. Asterisks denote two-tailed significance levels: significant at $* 90 \%$, $* * 95 \%, * * * 99 \%$.

rules (Buettner et al., 2012; Blouin et al., 2014). The magnitude of trade account borrowing, and its evident responsiveness to taxation, suggests that this may represent too narrow a view of corporate activity.

\section{REFERENCES}

Antràs, Pol, and C. Fritz Foley, "Poultry in Motion: A Study of International Trade Finance Practices," Journal of Political Economy 123 (2015), 809-852.

Auerbach, Alan J., "Taxation and Corporate Financial Policy” (pp. 12511292), in Alan J. Auerbach and Martin Feldstein, eds., Handbook of Public Economics, vol. 3 (Amsterdam: North-Holland, 2002).

Blouin, Jennifer, Harry Huizinga, Luc Laeven, and Gaëtan Nicodème, "Thin Capitalization Rules and Multinational Firm Capital Structure," International Monetary Fund working paper 14/12 (2014).

Bond, Stephen and Jing Xing, "Corporate Taxation and Capital Accumulation," Oxford University Centre for Business Taxation working paper 10/15 (2010).

Brennan, Michael, Vojislav Maksimovic, and Josef Zechner, "Vendor Financing," Journal of Finance 43 (1988), 1127-1141.

Brick, Ivan E., and William K. H. Fung, "Taxes and the Theory of Trade Debt," Journal of Finance 39 (1984), 1169-1176.

Buettner, Thiess, Michael Overesch, Ulrich Schreiber, and Georg Wamser, "The Impact of Thin-Capitalization Rules on the Capital Structure of Multinational Firms," Journal of Public Economics 96 (2012), 930-938.

Burkart, Mike, and Tore Ellingsen, "In-Kind Finance: A Theory of Trade Credit," American Economic Review 94 (2004), 569-590.

Chirinko, Robert S., Steven M. Fazzari, and Andrew P. Meyer, "How Responsive Is Business Capital Formation to Its User Cost? An Exploration with Micro Data," Journal of Public Economics 74 (1999), 53-80.

Cunat, Vicente M., "Trade Credit: Suppliers as Debt Collectors and Insurance Providers," Review of Financial Studies 20 (2007), 491-527.
Da Rin, Marco, Marina Di Giacomo, and Alessandro Sembenelli, "Entrepreneurship, Firm Entry, and the Taxation of Corporate Income: Evidence from Europe," Journal of Public Economics 95 (2011), 1048-1066.

Desai, Mihir A., C. Fritz Foley, and James R. Hines Jr., "Repatriation Taxes and Dividend Distortions," National Tax Journal 54 (2001), 829-851.

"The Costs of Shared Ownership: Evidence from International Joint Ventures," Journal of Financial Economics 73 (2004a), 323374.

"A Multinational Perspective on Capital Structure Choice and Internal Capital Markets," Journal of Finance 59 (2004b), 24512487.

"Capital Controls, Liberalizations, and Foreign Direct Investment," Review of Financial Studies 19 (2006), 1433-1464.

Desai, Mihir A., and Austan D. Goolsbee, "Investment, Overhang, and Tax Policy," Brookings Papers on Economic Activity 2 (2004), $285-338$.

Djankov, Simeon, Tim Ganser, Caralee McLiesh, Rita Ramalho, and Andrei Shleifer, "The Effect of Corporate Taxes on Investment and Entrepreneurship," American Economic Journal: Macroeconomics 2 (2010), 31-64.

Fabbri, Daniela, and Anna Maria C. Menichini, "Trade Credit, Collateral Liquidation and Borrowing Constraints," Journal of Financial Economics 96 (2010), 413-432.

Fisman, Raymond, and Inessa Love, "Trade Credit, Financial Intermediary Development and Industry Growth," Journal of Finance 58 (2003), 353-374.

Giannetti, Mariassunta, Mike Burkart, and Tore Ellingsen, "What You Sell Is What You Lend? Explaining Trade Credit Contracts," Review of Financial Studies 24 (2011), 1261-1298.

Graetz, Michael J., and Deborah H. Schenk, Federal Income Taxation: Principles and Policies, 6th ed. (New York: Foundation Press, 2009).

Graham, John R., "Debt and the Marginal Tax Rate," Journal of Financial Economics 41 (1996), 41-73.

"How Big Are the Tax Benefits of Debt?" Journal of Finance 55 (2000), 1901-1941. 
Hassett, Kevin A., and R. Glenn Hubbard, "Tax Policy and Business Investment" (pp. 1293-1343), in Alan J. Auerbach and Martin Feldstein, eds., Handbook of Public Economics, vol. 3 (Amsterdam: North-Holland, 2002).

Hines, James R., Jr., and Eric M. Rice, "Fiscal Paradise: Foreign Tax Havens and American Business," Ouarterly Journal of Economics 109 (1994), 149-182.

Huizinga, Harry, Luc Laeven, and Gaetan Nicodeme, "Capital Structure and International Debt Shifting," Journal of Financial Economics 88 (2008), 80-118.

Klapper, Leora, Luc Laeven, and Raghuram Rajan, "Trade Credit Contracts," Review of Financial Studies 25 (2012), 838-867.

Lee, Yul W., and John D. Stowe, "Product Risk, Asymmetric Information, and Trade Credit," Journal of Financial and Ouantitative Analvsis 28 (1993), 285-300.

Long, Michael S., Ileen B. Malitz, and S. Abraham Ravid, "Trade Credit, Quality Guarantees, and Product Marketability," Financial Management 22 (1993), 117-127.
Love, Inessa, Lorenzo A. Preve, and Virginia Sarria-Allende, "Trade Credit and Bank Credit: Evidence from Recent Financial Crises," Journal of Financial Economics 83 (2007), 453-469.

Meltzer, Allan H., "Mercantile Credit, Monetary Policy, and Size of Firms," Review of Economics and Statistics 42 (1960), 429-437.

Mian, Shehzad L., and Clifford W. Smith Jr., "Accounts Receivable Management Policy: Theory and Evidence," Journal of Finance 47 (1992), 169-200.

$\mathrm{Ng}$, Chee K., Janet Kiholm Smith, and Richard L. Smith, "Evidence on the Determinants of Credit Terms Used in Interfirm Trade," Journal of Finance 54 (1999), 1109-1129.

Petersen, Michell A., and Raghuram G. Rajan, "The Benefits of Lender Relationships: Evidence from Small Business Data," Journal of Finance 49 (1994), 3-37.

"Trade Credit: Theories and Evidence," Review of Financial Studies 10 (1997), 661-691.

Ramey, Valerie A., "The Source of Fluctuations in Money: Evidence from Trade Credit," Journal of Monetarv Economics 30 (1992), 171-193. 


\section{This article has been cited by:}

1. Haibo Yao, Yiling Deng. 2018. Managerial incentives and accounts receivable management policy. Managerial Finance 44:7, 865-884. [Crossref]

2. Nisar Ahmad, Mian Sajid Nazir, Bilal Nafees, Stephanos Papadamou. 2018. Impact of financial development and credit information sharing on the use of trade credit: Empirical evidence from Pakistan. Cogent Economics \& Finance 6:1, 1-17. [Crossref]

3. Sadok El Ghoul, Xiaolan Zheng. 2016. Trade credit provision and national culture. Journal of Corporate Finance 41, 475-501. [Crossref] 